UKRAINIAN EPIC AND HISTORICAL SONG 
This page intentionally left blank 


\section{Ukrainian Epic and Historical Song: Folklore in Context}

NATALIE KONONENKO

UNIVERSITY OF TORONTO PRESS

Toronto Buffalo London 
(C) University of Toronto Press 2019

Toronto Buffalo London

utorontopress.com

Printed in the U.S.A.

ISBN 978-1-4875-0263-8 (cloth)

Printed on acid-free paper with vegetable-based inks.

\section{Library and Archives Canada Cataloguing in Publication}

Kononenko, Natalie O., author

Ukrainian epic and historical song : folklore in context /

Natalie Kononenko.

Includes bibliographical references and index.

ISBN 978-1-4875-0263-8 (hardcover)

1. Dumy, Ukrainian - History and criticism. 2. Dumy, Ukrainian -

Translations into English. I. Title.

ML3690.K825 2019 782.42162'91791 C2017-907525-X

Publication of this book was made possible, in part, by the financial support of the Shevchenko Scientific Society of Canada.

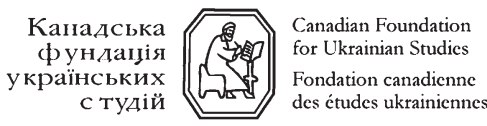

This publication was made possible in part by the financial support of the Canadian Foundation for Ukrainian Studies.

University of Toronto Press acknowledges the financial assistance to its publishing program of the Canada Council for the Arts and the Ontario Arts Council, an agency of the Government of Ontario.

Canada Council for the Arts
Conseil des Arts du Canada

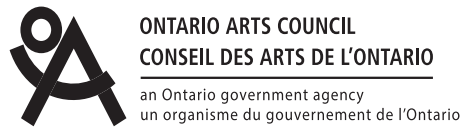


To Len,

Staunch defender of all things Ukrainian 
This page intentionally left blank 